\title{
ARTICLES
}

\section{An Actor Approach to Mediatization}

\section{Linking Politicians' Media Perceptions, Communication Behaviour and Appearances in the News}

Pauline Ketelaars \& Peter Van Aelst ${ }^{*}$

\begin{abstract}
In the light of the broader debate on the mediatization of politics, this study wants to better understand how the media perceptions and media behaviour of politicians are related to their appearances in the news. We opt for an innovative actor-centred approach to actually measure the views and actions of individual politicians. We combine surveys conducted with 142 Belgian representatives with data on politicians' external communication behaviour and on their appearances in television news, newspapers and news websites. The results show that media behaviour is not so much related to beliefs of media importance. We do find a significant positive relationship between strategic media behaviour and media attention suggesting that politicians who put in more effort appear more often in various news media. However, this positive relationship depends on the specific form of strategic communication and the political position of the legislator. Our study adds to the mediatization literature by showing how and when politicians are successful in obtaining media attention.
\end{abstract}

Keywords: mediatization, politicians, news media, media perceptions, news management.

\section{Introduction}

The efforts politicians make to manage the news are increasingly relevant. Since the 1960s politicians have gradually lost control over how politics is communicated and interpreted in the public sphere. We witness a process of mediatization in which journalists are more guided by their own routines and standards and less by what political actors deem important. Correspondingly, politicians adapted to

* Pauline Ketelaars was a postdoctoral researcher of the Fonds Wetenschappelijk Onderzoek (FWO). Her main research interests are political communication and social movements. Peter Van Aelst is a research professor at the department of political science at the University of Antwerp and a founding member of the research group 'Media, Movements and Politics' (M2P). His research focuses on political communication. Corresponding author: peter.vanaelst@uantwerpen.be. 
the media logic, the rules, formats and routines the mass media employ to cover current affairs. There is a booming literature on this adaptation process, called the 'mediatization of politics' (Blumer and Kavanagh 1999; Esser and Strömbäck 2014b; Strömbäck 2008). This mediatization process implies that politicians no longer think about the media only during elections, but almost permanently reflect on how their words and actions play out in the media (Davis 2010). Their belief in the power of the media is also reflected in their behaviour. Politicians and parties have professionalized their communication strategies and are involved in a permanent campaign to keep their visibility high and to gain attention for their interpretation of societal problems (Brants and Voltmer 2011).

Although the literature on news management and the mediatization of politics is growing steadily, several questions remain unanswered. As Strömbäck and Van Aelst (2013) point out, the concept of mediatization is often referred to in the political communication literature, but it is less used to guide thorough empirical research. The evidence about the mediatization of politics is generally unsystematic and often anecdotal. This is partly due to the fact that the concept is mostly used to describe the broad, aggregate process of political adaptation, but much less to actually study and understand the views and actions of individual politicians. In this study we opt for an actor-centred approach, guided by two specific research questions. Following the mediatization hypothesis, our first question deals with the link between politicians' media perceptions and their behaviour: To what extent is the strategic media behaviour of politicians connected to their perceptions of media importance? Several studies have indicated that parliamentarians strongly believe in the power of the media (e.g. Lengauer, Donges and Plasser 2014; Van Aelst and Walgrave 2011). However, the extent to which these perceptions are linked to their behaviour is much less clear (Cohen, Tsfati and Sheafer 2008; Matthes, Maurer and Arendt 2019). The second question focuses on the link between politicians' communication behaviour and media success: To what extent is strategic media behaviour connected to media appearances? While political candidates seem to spend a lot of energy attempting to meet journalistic criteria, few studies empirically investigate the activities by which they try to shape news coverage (Gershon 2012), and empirical studies on whether adaptation to the news media logic actually leads to media access are limited.

To answer both research questions, we use a twofold, subsequent design. First, we look at media perceptions of politicians and how these are linked with their communication behaviour (RQ1). Using surveys conducted in 2018 with Belgian Members of Parliament (MPs) $(\mathrm{N}=142)$, we measure to what extent politicians believe appearing in news media is important (for their personal election results, to get a good position on their party's ballot list and to what extent traditional media are more important than social media to reach voters). We also use these surveys to ask politicians about communication behaviour that would be difficult to measure directly (contacts with journalists, employees to manage media and media trainings). We complement the survey information with behavioural data on politicians' external communications (press conferences, press releases and tweets). Subsequently, we explore the connection between politicians' communication behaviour and their number of appearances in television 
news, print newspapers and news websites (RQ2). Our reliance on cross-sectional data implies that we will not study mediatization as process over time, but rather the degree to which politicians' thinking and behaviour is mediatized anno 2018.

We are aware of the fact that politicians' quantity of media attention (number of appearances) does not tell the whole story - we do not account for how politicians are covered. However, we argue that for most parliamentarians - hardly known by the public at large - getting some media attention is key. Moreover, we believe our study goes beyond existing research in at least two ways. First, we move away from the concept of mediatization as an all-embracing concept that deals with the power struggle between 'media' and 'politics'. Rather we opt for an actor approach at the individual level that allows to study variation in the views and actions of politicians. A central interest running through both research questions is the difference between different types of politicians. From previous studies we know that the distribution of media attention is highly unequal (Kruikemeier, Gattermann and Vliegenthart 2018; Tresch 2009). Although all politicians aim to receive media attention, few actually get it on a regular basis. Since we know that political status is the crucial factor that drives media attention (Vos 2014), we devote special attention to differences between MPs with a relative strong parliamentary position or previous government experience - so-called frontbench MPs - and less prominent, backbench MPs who have no official position in parliament nor previously held a position that distinguishes them from the rest.

Second, we use a broad perspective on politicians' communication strategies and its effects. Previous research has often focused on one specific kind of 'media accommodation', for instance having employees who do media work (Van Aelst, Sehata and Van Dalen 2010) or the press releases politicians send to the media (Meyer, Haselmayer and Wagner 2020). This study includes both short-term and long-term ways in which individual politicians can adapt their behaviour, and we investigate the use of both traditional (press releases and press conferences) and new, digital ways of communication (tweets). Finally, while scholars mostly investigate politicians' access to one type of media, we study two 'offline' channels (print newspapers and television news) and investigate attention for politicians on the most important Belgian news websites. By including online news media and social media in our design, we try to take into account that the media environment in which politicians are operating has structurally changed over the last decade.

\section{Towards an 'Actor-Centric' Approach on Mediatization}

The mediatization of politics can be considered as a broad structural process, or as Strömbäck and Esser (2014:6) define it: 'a long-term process through which the importance of the media and their spill-over effects on political processes, institutions, organizations and actors have increased'. Mediatization is seen as one of the most influential drivers of changes in politics during the last decades (Kriesi 2013). The initial mediatization literature stressed that this structural 
process meant that the power of the media increased at the expense of politics and that political actors were forced to adapt. Strömbäck (2008:235), in his seminal article, noted that in the final stage of the mediatization process political actors would be 'governed' by the media logic. More recent studies, however, stress the idea that the media matter because politicians strategically choose to adapt to the media logic and rather use the media in their competition with other politicians (Landerer 2013; Marcinkowski and Steiner 2014; Van Aelst et al. 2014). Also, Esser and Strömbäck (2014a:227) have acknowledged a shift from a 'media-centric' to an 'actor-centric' perspective in mediatization research. This means that more scholars start to investigate how parties and politicians proactively try to use the media to reach certain political goals (Strömbäck and Van Aelst 2013; Van Aelst and Walgrave 2016). As a consequence, current mediatization research treats the adaptation to, and use of, the media no longer as a given, but as an empirical question. This study follows that tradition, also by integrating mediatization studies with literature on communication strategies and news management.

There is little doubt that politicians have invested in media expertise and have surrounded themselves with communication experts. This evolution is mostly studied at the government level where powerful political leaders have the means to structurally invest in news management. Studies have shown how this is done in the United States (Bennett, Lawrence and Livingston 2007; Manheim 1998), but also in European countries such as Germany (Pfetch 1998) and France (Kuhn 2005). At the level of individual politicians, our knowledge is mainly limited to the United States, where studies show that Members of Congress and Senators invest heavily in their strategic communication efforts (Cook 1986; Sellers 2010). The extent to which individual parliamentarians in multiparty systems use news management strategies is much less clear. As Brants and Van Praag (2006) show, the practice of political communication in countries with a democratic corporatist model such as Belgium (Hallin and Mancini 2004) significantly differs from Anglo-American systems. Due to consensus democracy with a central position for political parties and a strong public broadcasting tradition, the Belgian political system confines the necessity of active news management for individual politicians. Our analyses focus solely on the Belgian (Flemish) case, but in the discussion section we will elaborate on how our findings should be interpreted in a comparative perspective.

Our goal is to find out to what extent MPs have adapted to the news media logic and whether this adaptation is actually connected to media access. Theoretically, we distinguish between two aspects of this process. First, we investigate how convinced politicians are that appearing in the news media is important and to what extent these beliefs are linked to their strategic media behaviour. Second, we test whether this media behaviour can help politicians to gain media coverage.

RQ1: To what extent is the strategic media behaviour of politicians connected to their perceptions of media importance?

When asked directly, many political elites agree that the media exert substantial power to set the political agenda and that media affect their political careers 
(Fawzi 2018; Lengauer et al. 2014; Maurer 2011; Strömbäck 2011; Van Aelst et al. 2008). However, only few studies have tested whether perceptions of media importance actually affect politicians' behaviour and whether this type of attention remains that crucial in the social media era (see further).

For individual representatives, getting in the media is not a goal in itself, but a means to reach other purposes. For a politician, one of the central goals is to get (re-)elected. In multiparty systems, the news media can help to reach that goal in two ways. Firstly, media appearances help politicians to get known by the public. As citizens are unlikely to vote for candidates they know little about, and because most people obtain their knowledge about politicians via the news (Arnold 2004), media exposure helps politicians to get votes (Kahn and Kenney 2002). Second, in political systems like Belgium, political parties decide which representatives get a (high) place on the ballot list. In mediatized democracies, political parties will at least partly base the selection of their representatives based on media performance (Sheafer and Tzionit 2006). A lot of exposure can boost one's position within the party and this may result in a higher ranking on the ballot list (Davis 2010). This ballot list position, in turn, is crucial in terms of personal electoral success (van Erkel and Thijssen 2016). In order to answer our first research question, we asked politicians in a survey about the extent to which they perceive appearing in the news media to be important to reach these two prominent goals. Additionally, we asked them about a related aspect that has become more relevant in recent years; the importance of the traditional mass media to reach voters compared to the rising importance of social media. Since social media allow for more direct communication with voters, and since they are a way to bypass the critical questions and framing of journalists (Klinger and Svensson 2015), politicians might attribute less importance to the mediating role of classical news media these days. On the other hand, social media such as Twitter are often used to attract the attention of journalists. In that respect, social media remain an instrument to influence the traditional media rather than a new medium in itself (Harder, Sevenans and Van Aelst 2017).

In their seminal study, Cohen et al. (2008) found that perceptions of Israeli parliamentarians about media power positively affect their efforts to achieve media coverage. Matthes et al. (2019) found a similar connection between perceptions and media behaviour. They showed that MPs (from Switzerland, Germany and Austria) who have more hostile perceptions of the media have less contacts with journalists. On the other hand, however, a recent study among German parliamentarians did not confirm that media perceptions correlate with politicians' strategic behaviour. Bernhard, Dohle and Vowe (2016) expected that 'parliamentarians use Facebook and Twitter more extensively when they believe that these social media tools have a strong political influence on the public, journalists, and other politicians'. Their study indicates that politicians use social media regardless of whether they expect it to have an impact on journalists or the general public. These limited and mixed findings require further investigation. Moreover, Cohen et al. measure politicians' media behaviour via just one general survey item, whereas Matthes et al. only study the effect of perceptions on contact with journalists and the study of Bernhard et al. is limited to online activities. As dis- 
cussed below, we will test the relationship between perceived media power and six types of media activities. As such, we will be able to test more comprehensively whether mediatization is indeed 'driven to a large extent by politicians' perceptions that media have a powerful influence on politics' (Tsfati 2017:572).

\section{RQ2: To what extent is strategic media behaviour connected to media appearances?}

Mediatization does not only involve the adaptation of politicians' perceptions, it also implies that politicians alter their behaviour in order to gain media attention. We differ between short-term news management behaviour - actions aimed to 'immediately' affect media coverage - and long-term news management - more structural ways of accommodating to the news media logic that should improve access to the media arena. This later type of media behaviour is not related to a specific event or message, but can rather create a structural basis for success regarding politicians' direct media actions.

The short-term way for politicians to promote themselves and their agenda is through the provision of 'information subsidies' (Gandy 1982), such as organizing press conferences or other media events. These happenings make it easy and cheap for journalists to make news. While organizing press conferences requires time and effort from politicians, sending out press releases is a relatively easy method to proactively provide journalists with information (Boumans 2018). In particular, as journalists have short deadlines to provide (online) news, press releases not only provide journalists with a topic to cover, but also with the right words to do so (Jacobs 1999). As a consequence, it is no surprise that press releases are frequently and successfully used by different types of politicians across countries to promote themselves or their issue agenda (e.g. Gershon 2012; Kiousis et al. 2009). During the last years the toolkit to provide journalists with information subsidies has expanded. In particular, Twitter is increasingly used by politicians to reach out to their followers, but mainly to try to influence journalists (Jungherr 2014b; Parmelee 2014). According to Parmelee (2014:446), tweets have the potential to be more influential than press releases as they simultaneously reach a wide public that reacts to them and because they force journalists to follow up on the current debate. On the other hand, the extreme fast and cheap nature of this new type of information subsidy may create information overload for journalists. Nevertheless, recent studies show that tweets from (important) politicians, at least in election time, often set the agenda of both new and traditional media (Harder et al. 2017; Jungherr 2014a; Wells et al. 2016).

Besides providing journalists with information subsidies, there are various structural and organizational ways in which political parties and politicians can accommodate their behaviour to the media logic. This study focuses on three structural or long-term means of accommodating to the news media by individual representatives. First, politicians can ask their personnel to manage and respond to the mass media. Although having professional support to deal with the media is hardly the norm for European politicians, previous research found that having a spokesperson increases the chance of having frequent contacts with journalists (Van Aelst et al. 2010). 
Second, individual politicians can follow media trainings to increase their knowledge of how the media work and how they should respond to journalists. Little is known about this practice of media adaptation. We know that political parties in countries such as the United Kingdom, Sweden and Norway started offering media training to their political candidates in the 1970s, as part of their effort to professionalize their media strategy (Allern 2011; Negrine and Lilleker 2002). During media training, politicians can learn how to behave more in line with media logic and formats by, for instance, providing journalists with sharp sound bites. Compared with early media coaching, modern media training increasingly teaches politicians how to be proactive and how to use the media for their own objectives (Rosenbaum 2016). Finally, having frequent contact with journalists can be an important tactic for politicians to influence media coverage (see e.g. Gans 1980; Nimmo and Geyer 2014). Although both politicians and journalists often publically complain about each other, behind the scenes they routinely keep on working in good understanding and cooperation (Kumar and Jones 2005). For politicians these interactions can lead to a cooperative context that can improve their chances to pass the media gates.

\section{Data and Methods}

We use three types of data in this article: surveys with politicians, politicians' external communications and news media data. All external communications and news media data were gathered during one year. The research period for the data gathering was from 1 July 2017 until 30 June 2018, only for television news the data were gathered from 1 January 2017 until 31 December 2017. The survey data collection was part of a larger project for which a series of interviews with politicians were conducted between March and July 2018. The representatives were interviewed by a team of trained and experienced researchers who visited them in their Brussels offices. We contacted the entire population of Belgian Dutch-speaking MPs holding office at the federal level or at the regional level of Flanders. In total, 153 out of the population of 212 politicians participated, leading to a response rate of $72 \% .^{1}$ This is very high for elite research (see e.g. Deschouwer and Depauw 2014 for a study among MPs in 15 countries, with response rates ranging between 13 and 43\%). 142 politicians answered all questions that are used in this study. We use the surveys in order to measure politicians' perceptions of media importance and their long-term media strategies (see below).

\subsection{Perceptions of Media Importance}

Politicians were asked to indicate to what extent they agree or disagree with three statements on a scale from 1 to 5 (1: totally disagree to 5: totally agree). The first statement was 'For the personal election result of a politician it is more important to influence policy than to get in the media.' (media importance: election result). We reversed these scores so that high scores mean that getting in the media is more important than influencing policy for personal election results. The second state- 
ment was: 'Getting in the media helps me to get a good position on the ballot list of my party' (media importance: ballot list). Finally, the third statement wording was: 'In order to reach voters, social media are better suited than traditional media (like radio, television and newspapers)' (media importance: traditional media). Again, we reversed the scores. High scores on this variable now mean that traditional media are more important than social media to reach voters. ${ }^{2}$ See Appendix A for the frequency distributions of the media perceptions across frontbench and backbench MPs.

\subsection{Media Strategies}

In order to measure politicians' short-term media strategies, we gathered three types of politicians' external communications. First, the number of press releases measures the total number of press releases that were sent by a politician during the one-year research period (July 2017-2018). In order to collect press releases, we subscribed to all Flemish political parties' press mailing list. For each politician we calculate the number of press releases that he or she sent out. During the research period, $17 \%$ of the MPs in our sample did not send out any press releases, $35 \%$ distributed between one and three, $33 \%$ spread three to ten and $15 \%$ sent out more than ten press releases. The second indicator of short-term strategic media communication is the number of press events. This variable measures the number of press events or media happenings that were held by a politician. Media events were collected via the agenda of Belga, the Belgian press agency. Every agenda event in which a politician of the sample was mentioned was incorporated in the data set. Media events that were announced via politicians' press mailing lists (see above) were coded as press events as well. Almost two thirds of MPs (64\%) were not part of a press event or media happening, $25 \%$ of the MPs organized one or two press conferences and only $8 \%$ arranged three or more. Third, the variable number of tweets measures the total number of tweets that were sent by a politician during the one-year research period. Retweets are not included in this measure. We divide the number of tweets by 100 to make sure that potential effects are observable in our regression analyses. Although sending tweets requires little effort, ten politicians do not have a Twitter account or did not tweet any message. More than a fifth (22\%) sent between one and 50 tweets (less than one per week on average), $39 \%$ of the politicians tweets between one and five times a week, while $32 \%$ sent more than 250 tweets.

There are some important differences between frontbench and backbench MPs when it comes to providing these three types of information subsidies. See Appendix B for the distributions of these variables across backbench and frontbench MPs.

The variables to measure more structural or long-term media behaviour were gathered via the surveys with politicians. First, we asked 'How many full-time personal employees do you have? Please fill in the total percentage points, where $50 \%$ means you have one half-time employee, and where $200 \%$ means you have two full-time employees'. When the answer was higher than '0', we asked: 'What percentage of the working hours of these employees is allocated to external communication and contacts with the media?' Using both questions, we calculate the 
total time of a politician's employee(s) that goes to external communication and contacts with the media (employees media time). Most MPs have only one employee that can devote a (small) part of his or her time to media communication. For a third of the politicians, not more than 10 hours of their employees' work time is devoted to media affairs. Six per cent say that it consumes 50 hours or more of their employees' time. Second, in order to measure the frequency of politicians' contact with journalists we asked: 'Think about an average month during the political year. How often per month do you personally have contact with a political journalist (both formally and informally)?' We recoded some outliers on this variable to a maximum of 25 contacts per month. Again, the variation between MPs is very outspoken: $35 \%$ of the MPs say they informally or formally have contact maximum two times a month while $21 \%$ have contact with journalists ten times or more per month. This variation is partly related to the position of the MP (see Appendix C). Third, we asked politicians about the number of times they had media training: 'How often did you personally have media training?' Twelve per cent of the MPs indicated that they never had media training. A large group (42\%) received media training once or twice and $6 \%$ said they had media trainings more than four times. We recoded some outliers on this variable to a maximum of ten media trainings.

\subsection{Media Appearances}

In order to measure the presence of these politicians in the news, we gathered three different news media data: television news, print newspaper articles and online news articles. For appearances in television news we are grateful to the Electronic News Archive (ENA) that collects and codes all evening newscasts of the two main Flemish broadcasters: the public broadcaster (VRT) and the commercial channel (VTM). We count for each politician the number of times he or she appeared in a newscast (television news appearances) during one year including both speaking and non-speaking appearances. Furthermore, via the Belgian 'Gopress' search engine (www.gopress.be), all print newspaper articles in which one or more politicians were mentioned were gathered. A Python script was used to automatically gather all articles of the seven most important Flemish newspapers (De Standaard, De Morgen, De Tijd, Het Laatste Nieuws, Het Nieuwsblad, Gazet van Antwerpen and Het Belang van Limburg). The data was used to count the total number of print newspaper articles in which each politician was mentioned (newspaper appearances). Online news was gathered by scraping four times a day all the articles that appeared on the relevant RSS feeds of eight news websites: vrt.be, knack.be, destandaard.be, demorgen.be, hln.be, nieuwsblad.be, gva.be and hbvl.be. All these websites are linked to offline media since Flanders does not have substantial online-only news media. Only the articles that were available without a subscription for these media outlets were selected. We take the total number of online articles in which a politician was mentioned to measure online news appearances. See Appendix D for the frequency distributions of these three variables. 


\subsection{Regression Analyses and Control Variables}

To answer RQ1, we analyse the effects of perceptions of media importance on strategic media behaviour. We run six regressions, one for each measure of a politician's media behaviour (three short term and three long term). RQ2 deals with the effect of media behaviour on appearances in news media. We run three regressions as we have three measures of media attention. All dependent variables of these nine regressions are count data with overdispersion: the conditional variances exceed the conditional means. We therefore use negative binomial regressions. Negative binomial regressions have an extra parameter to model the overdispersion. The distributions of the variables - and their mean and variance scores - can be found in Appendices B-D.

In our analyses, we account for several characteristics of the politicians that might influence their relationship with the media. First and foremost, we expect that political status matters. Therefore, we differ between regular MPs or socalled backbench MPs (0), and more important, frontbench MPs (1): commission chairs, former ministers and state secretaries, and present or former party (floor) leaders and speakers of parliament. Our sample contains 94 backbench and 48 frontbench MPs. Second, we control for whether a politician is part of an opposition party (0) or of a party in government (1) (member government party). Third, we account for the number of preference votes a politician got in the previous elections, as a proxy for how well known a politician is. Because candidates participate in different electoral constituencies with different numbers of voters, the potential number of preference votes a politician can receive varies. We therefore divide the number of preference votes by the total number of preferential votes cast in a district. We also code the representatives' political position in parliament. Finally, as we know that media attention for female and male politicians can differ (Tresch 2009; Vos 2013), we add sex as a control variable: male (0), female (1).

\section{Results}

\subsection{Research Question 1}

Our first research question is: To what extent is the communication behaviour of politicians connected to their views on the influence of the news media? We start by looking at some descriptive results of politicians' perceptions of the importance of media coverage. Overall, and in line with previous research, parliamentarians strongly believe in the power of the media (see Appendix A). Interestingly, the statement politicians most widely agree upon (73\%) is that getting in the media helps them to get a good position on the ballot list of their party. A similar - yet less outspoken - picture arises regarding the effect of media presence on personal election results. Almost seven out of ten (68\%) politicians think that it is more important to get in the media to gain votes than to influence policy. Politicians' opinions are more dispersed when it comes to the power of traditional media versus social media: about one out of four (27\%) neither agrees nor disagrees with this statement, four out of ten (40\%) are convinced that social media 
are better suited to reach voters while a third (33\%) of the representatives believe that traditional media are still the best way to get to citizens. There are no important differences between frontbench and backbench MPs when it comes to perceptions of media importance. 


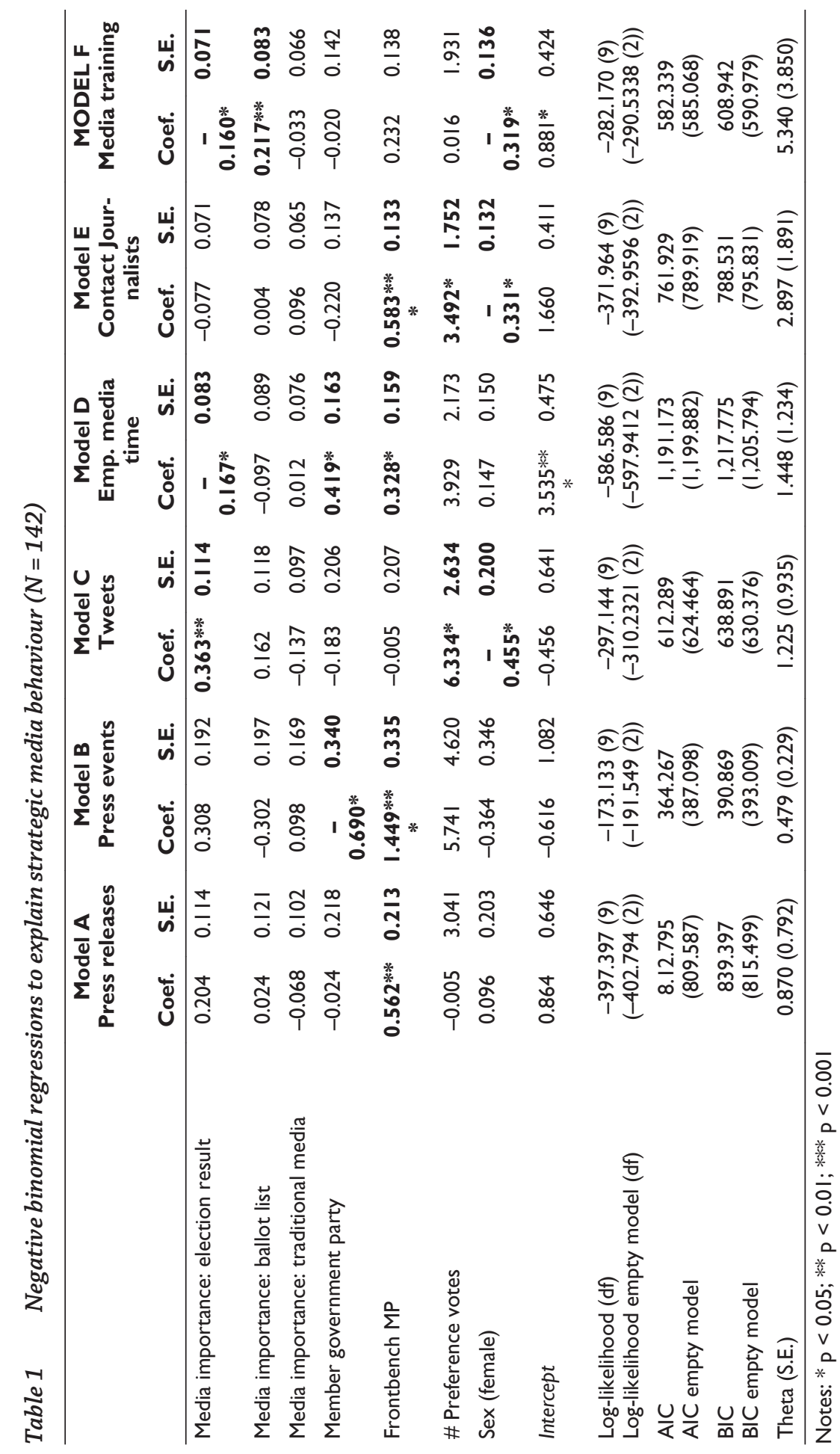


The question now is to what extent politicians' perceptions of media power can help to explain strategic media behaviour. Are politicians who perceive the media to be powerful also more active in their media efforts? In short, the answer is not much. Table 1 shows regressions with the six different forms of media behaviour as the dependent variables. None of the three media perceptions correlate with the number of press releases nor with the number of press conferences (Models A and $B$ ). The number of tweets (Model C) is slightly influenced by the perceived importance of news media for personal election results. The same statement has small negative effects on employees' media time and media training (Models D and F). This seems to suggest that the media's perceived influence on electoral success is linked to more short-term social media behaviour and to somewhat less investments in more long-term strategies. These rather limited correlations contrast with the much more outspoken relationship with the position of the MP. Frontbench MPs are much more active in their communication strategy towards the media: they send more press releases, organize more press events, ask for more media support from their employee(s) and have much more frequent contacts with journalists. The individual electoral capital of a parliamentarian, measured by the number of preferential votes, also matters to some extent. Popular politicians tweet more and have more frequent contacts with journalists. Overall, the differences between government and opposition MPs are limited, and gender differences are modest as well with female politicians being slightly less active on several forms of strategic media behaviour. In sum, differences in politicians' perceptions of the importance of the news media are only slightly correlated with the differences between politicians' media efforts. Politicians who think traditional news media are more important to reach voters than social media, and who think news media are important to get re-elected and to gain a high position on the ballot list, are not necessarily more active in their strategic media behaviour. 


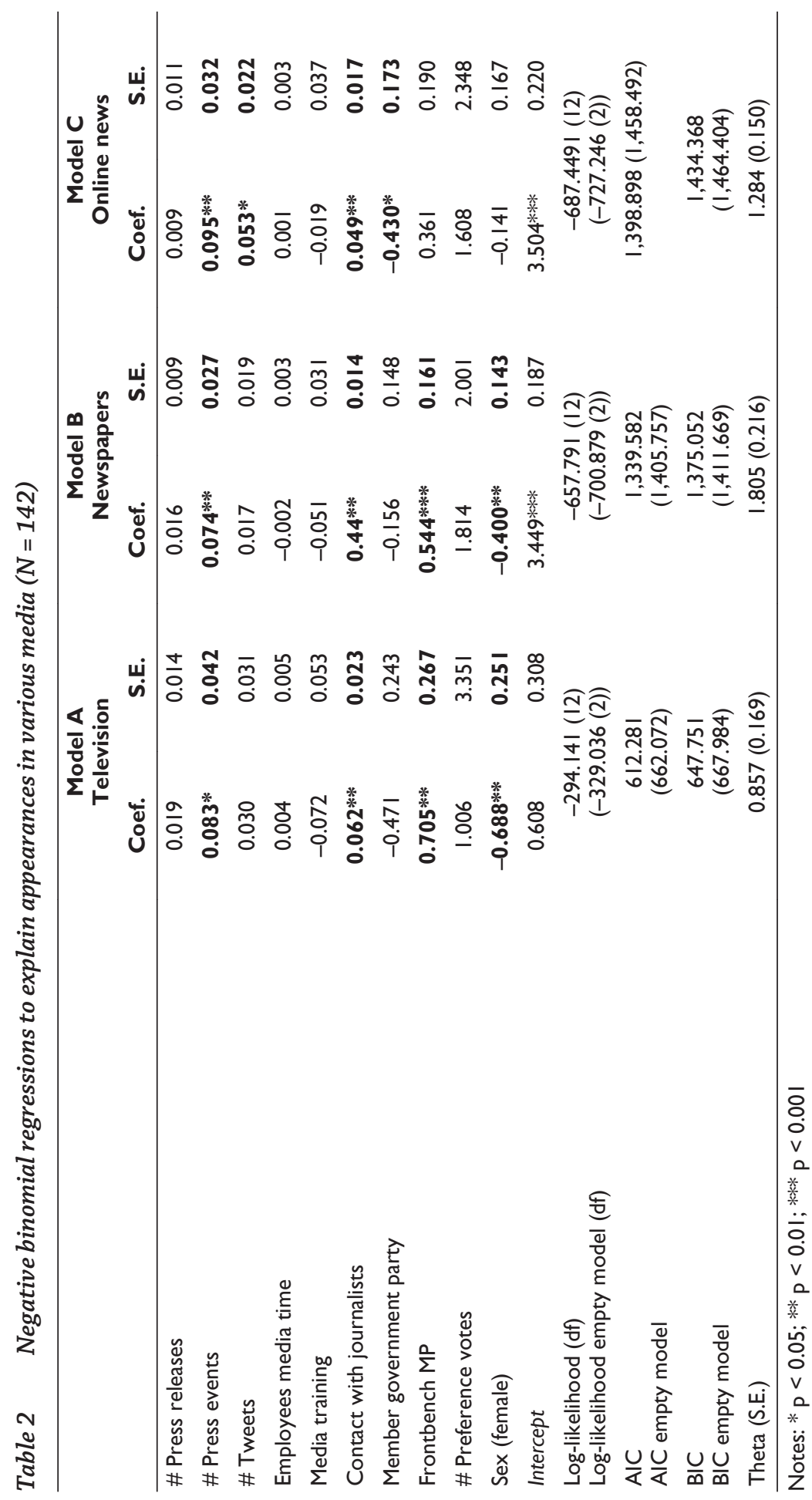




\subsection{Research Question 2}

The second, subsequent research question of this study was: To what extent is behavioural adaptation to the news media logic connected to media access? In order to answer this question, we again run regression analyses (see Table 2) and investigate whether politicians' appearances in television news, print newspapers and online news are correlated with their media efforts. In order to interpret effect sizes, we will report in the text predicted probabilities while keeping other variables at representative values.

First of all, the regression results show that sending out press releases is not significantly correlated with media attention. Yet, organizing press conferences and media happenings does help to gain media visibility. Predicted probabilities indicate that politicians who organized no press conferences on average had 30 newspaper, 28 online and 1.4 TV appearances, while politicians who organized two events were covered in 35 newspaper articles, 33 online articles and 1.8 television newscasts. Hence, holding a press conference does pay off. Sending out tweets is linked to media attention as well. Yet, interestingly, Twitter only affects visibility on online media. A tweet is easily picked up by online news editors who need to make their stories fast; they can use the tweets of politicians to construct their news items. In line with previous studies, these tweets often do not remain part of the 'printed' news story the next day (Paulussen and Harder 2014). Politicians who sent about one tweet per week (50 tweets during the year) averagely appeared in 26 online news articles. The ones who tweet double as often appeared in 27 articles. Only rather active tweeters really feel the difference: the ones who tweet every day (350 during one year) were on average mentioned in 31 articles (predicted probabilities based on Model C).

The more long-term investments of politicians in news management seem to pay off a bit less. Investing in media training is not positively related to media attention, and we even find a negative effect on television appearances. Having an employee who devotes more time to dealing with the press also does not increase a politician's media visibility. The only structural media activity that matters is more frequent contacts with journalists. The fact that having regular contact with the people who make the news matters is not surprising. However, this variable might also be a consequence rather than the cause of media visibility. Politicians who often appear in the media meet journalists more regularly. This is partly confirmed by the positive effects of frontbench MPs on media appearances. Nevertheless, there is an effect even when controlling for the difference between frontbench and backbench MPs, which suggests that backbench MPs who have close contacts with journalists can benefit from this. Contact with a journalist once per month results on average in 1.4 appearances on television, 27 mentions in newspapers and 24 in online articles per year. Representatives who formally or informally have contact four times per month averagely appear 1.6 times on television, 31 times in the newspapers and 28 times online.

Finally, we control for the characteristics of the politicians. First, it is striking that the results for online media attention mirror the results for appearances on television and in print newspapers. While the position of a politician has a substantive effect on his or her offline coverage, this does not matter for online 
media. Similarly and in line with previous studies, female politicians are significantly less represented on TV and in newspapers, but they do not have a disadvantage on news websites. At the same time, politicians from opposition parties have an advantage online compared to government party members. The lower online attention for government MPs is probably a form of compensation for the vast media presence of their party members who are part of the cabinet as ministers and state secretaries (see also Van Aelst et al., 2008). As such, news websites are more egalitarian than television news and newspapers. It is a place where traditionally 'weaker' politicians can take the stage as well.

\section{Conclusion and Discussion}

In general, scholars agree that the world of politics is getting ever more mediatized and that political actors have adapted to the media and its logic. However, there is less agreement on the extent to which politicians' attempts to influence the media are related with their perceptions of media influence (RQ1) and how strategic communication behaviour is linked to politicians' access to the media arena (RQ2). Using an actor approach, focusing on the individual perceptions of politicians and their personal media behaviour, we addressed both questions.

First, our study showed that perceptions about the political influence of the news media are not strongly connected with politicians' behaviour. Their position in parliament seems much more relevant than their beliefs to explain the use of six forms of strategic communication. Not so much what they think about the media, but rather their political position determines how they try to access the media arena. How can this be explained? Some mediatization scholars might argue that the reason for this is that mediatization is hard to measure via traditional empirical research because it is a meta process that transcends discernible media effects at the individual level (Schulz 2004). Dealing with the media has become a natural part of politics for politicians, so much interwoven with their daily work that it has become hard to distinguish their perceptions of the media from their overall view of political reality. This line of reasoning finds some concrete support in our data. The lack of influence of perceptions might partly be explained by the relative strong agreement among MPs that attracting media attention is crucial for their political career. A large majority of politicians are convinced that media attention is relevant to convince both voters and party elites. Yet, if the lack of variance is the main explanation, the statement about social media being more important to reach voters than the traditional media should have explanatory power, as the perceptions of MPs vary considerably on this matter. However, we find that these varying views have no influence on media behaviour, not even on politicians' use of Twitter. This might be due to the fact that Twitter is mainly used by politicians to reach journalists, rather than the general public. In other words, the hybrid nature of the media landscape (Chadwick 2013), blending new and old media, might also make it hard to find an effect of media perceptions on politician's media efforts. 
Second, we studied how different forms of strategic media behaviour have an impact on politicians' appearances in the news. Overall, we can conclude that investing in strategic communication works, even when controlling for political position and the number of preference votes. Providing journalists with different types of information subsidies has a significant effect on the number of times a politician is mentioned in the news. Organizing press events, something which is done mainly by frontbench MPs, leads to more coverage on all types of news media platforms. Using Twitter is only beneficial to influence the coverage of news websites. In contrast to these forms of 'short-term' news management, more structural long-term forms of news management proved less relevant. Following media training and having more support from an employee in dealing with the media does not contribute to personal media attention. These findings seem to indicate that professionalizing your media skills and media support is not directly connected to your media success. This is in line with the idea that media popularity might be more related to personal characteristics that are not easy to obtain (nor measure) such as politicians' charisma, rhetoric qualities or energy level (e.g. Sheafer 2001). Having more frequent personal contacts with journalists, however, seems to pay off. Interacting with journalists leads to more coverage, but is probably also partly a consequence of appearing in the news more regularly.

This last finding brings us back to the causal relationship between media perceptions, media behaviour and media access. We started from the idea that perceptions are correlated with behaviour, and that this behaviour in turn is connected to access. We found fairly strong proof for the second relationship, but little for the first. The fact that contacts with journalists can be as much a result of media access as a cause also makes us cautious for strong causal claims. Detangling the virtuous interaction between visibility in the news and contacts with news makers requires more in-depth studies. Further studies could also go beyond the frequency of media attention and include tone or sentiment of the coverage. In addition, studying the concrete issues that were dominating the news might contribute to explain why some politicians did better in terms of media attention than others (e.g. Wolfsfeld and Sheafer 2006).

Despite these shortcomings, we believe our actor-centred approach helps to push the mediatization literature in a more empirical direction with more attention for the contingency of media effects. While scholars generally assume there is a direct link between perceptions of media power and politicians' activities to get into the news media, our results do not support this assumption. In line with Bernhard and colleagues (2016), we believe other factors such as the political position of a politician is much strongly linked to media behaviour than mere perceptions. More generally, this refers to the importance of taking into account the political context when studying mediatization. Although MPs are a fairly homogeneous group of politicians, differentiating between frontbench and backbench members matters: they use different strategies to influence the news, strengthening the unequal access to the media arena. Simultaneously, however, strategic communication behaviour does not only bear fruit for frontbench MPs but for backbench parliamentarians as well. In particular for online news media, the 
political status of the politician seems to matter less, and can therefore be a way for ordinary MPs to compete in the skewed competition for media attention.

Finally, we reflect on the generalization of our findings. The characteristics of the Belgian multiparty system, characterized by strong political parties, probably limit the demand for active news management, in particular for individual politicians. Furthermore, the resources Belgian politicians have to invest in news management are limited. These factors can explain the relatively low number of Belgian politicians that have full-time media employees and the fact that very few Belgian politicians frequently organize press events. This is quite different from the media practice of individual legislators in larger majoritarian systems such as the United Kingdom or the United States (Brown 2011). However, we do think that our main finding that political position trumps media perceptions travels across the board. The structural differences between politicians with a different political status in both their dealing with the media as their media attention have become a consistent finding in the literature. Our study confirms that the relatively small differences between politicians in parliament can also explain to a large extent how they relate and adapt to different old and new media. This finding also proves that using an actor-centred approach is insightful and adds to the mediatization literature by stressing the contingency of media adaptation by individual political actors.

\section{Notes}

1 The population consists of 212 members of parliament as the Flemish parliament has 124 members and there are 88 Dutch-speaking parliamentarians at the federal level.

2 The three perception variables cannot be used to create one scale. Cronbach's alpha of this scale is only 0.35 .

\section{References}

Allern, Sigurd. 2011. "PR, Politics and Democracy." Central European Journal of Communication 4(6):125-39.

Arnold, R. Douglas. 2004. Congress, the Press, and Political Accountability. Princeton, NJ: Princeton University Press.

Bennett, Lance, Regina G. Lawrence, and Steven Livingston. 2007. When the Press Fails. Political Power and the News Media from Iraq to Katrina. Chicago: University of Chicago Press.

Bernhard, Uli, Marco Dohle, and Gerhard Vowe. 2016. "Do Presumed Online Media Effects Have an Influence on the Online Activities of Politicians?” Policy \& Internet 8(1):72-90.

Blumer, Jay G. and Dennis Kavanagh. 1999. "The Third Age of Political Communication: Influences and Features." Political Communication 16(3):209-30.

Boumans, Jelle. 2018. “Subsidizing the News?” Journalism Studies 19(15):2264-82.

Brants, Kees and Philip van Praag. 2006. "Signs of Media Logic: Half a Century of Political Communication in the Netherlands." Javnost - The Public 13(1):25-40.

Brants, Kees and Katrin Voltmer, eds. 2011. Political Communication in Postmodern Democracy. Basingstoke: Palgrave Macmillan. 
Brown, Robin. 2011. "Mediatization and News Management in Comparative Institutional Perspective." Pp. 59-74 in Political Communication in Postmodern Democracy, edited by K. Brants and K. Voltmer. Basingstoke: Palgrave Macmillan.

Chadwick, Andrew. 2013. The Hybrid Media System: Politics and Power. Oxford, NY: Oxford University Press.

Cohen, Jonathan, Yariv Tsfati, and Tamir Sheafer. 2008. “The Influence of Presumed Media Influence in Politics Do Politicians' Perceptions of Media Power Matter?" Public Opinion Quarterly 72(2):331-44.

Cook, Timothy E. 1986. "House Members as Newsmakers: The Effects of Televising Congress.” Legislative Studies Quarterly 11(2):203-26.

Davis, Aeron. 2010. Political Communication and Social Theory. London: Routledge.

Deschouwer, Kris and Sam Depauw, eds. 2014. Representing the People: A Survey Among Members of Statewide and Substate Parliaments. Oxford, NY: Oxford University Press.

van Erkel, Patrick F. A. and Peter Thijssen. 2016. "The First One Wins: Distilling the Primacy Effect." Electoral Studies 44:245-54.

Esser, Frank and Jesper Strömbäck. 2014a. "A Paradigm in the Making: Lessons for the Future of Mediatization Research", pp. 223-42 in Mediatization of Politics. Understanding the Transformation of Western Democracies, edited by F. Esser and J. Strömbäck. Basingstoke: Palgrave Macmillan.

Esser, Frank and Jesper Strömbäck. 2014b. Mediatization of Politics: Understanding the Transformation of Western Democracies. Basingstoke: Palgrave Macmillan.

Fawzi, Nayla. 2018. "Beyond Policy Agenda-Setting: Political Actors' and Journalists' Perceptions of News Media Influence across All Stages of the Political Process." Information, Communication \& Society 21(8):1134-50.

Gandy, Oscar H. 1982. Beyond Agenda Setting: Information Subsidies and Public Policy. Norwood, NJ: Ablex Publishing Company.

Gans, Herbert J. 1980. Deciding What's News: A Study of CBS Evening News, NBC Nightly News, Newsweek, and Time. New York: Vintage.

Gershon, Sarah Allen. 2012. "Press Secretaries, Journalists, and Editors: Shaping Local Congressional News Coverage.” Political Communication 29(2):160-83.

Hallin, Daniel C. and Paolo Mancini. 2004. Comparing Media Systems: Three Models of Media and Politics. Cambridge: Cambridge University Press.

Harder, Raymond A., Julie Sevenans, and Peter Van Aelst. 2017. "Intermedia Agenda Setting in the Social Media Age: How Traditional Players Dominate the News Agenda in Election Times." The International Journal of Press/Politics 22(3):275-93.

Jacobs, Geert. 1999. Preformulating the News: An Analysis of the Metapragmatics of Press Releases. Amsterdam: John Benjamins Publishing.

Jungherr, Andreas. 2014a. "The Logic of Political Coverage on Twitter: Temporal Dynamics and Content." Journal of Communication 64(2):239-59.

Jungherr, Andreas. 2014b. Twitter in Politics: A Comprehensive Literature Review. SSRN Scholarly Paper. ID 2402443. Rochester, NY: Social Science Research Network.

Kahn, Kim Fridkin and Patrick J. Kenney. 2002. "The Slant of the News: How Editorial Endorsements Influence Campaign Coverage and Citizens' Views of Candidates." American Political Science Review 96(2):381-394.

Kiousis, Spiro, Soo-Yeon Kim, Michael McDevitt, and Ally Ostrowski. 2009. "Competing for Attention: Information Subsidy Influence in Agenda Building during Election Campaigns." Journalism \& Mass Communication Quarterly 86(3):545-62.

Klinger, Ulrike and Jakob Svensson. 2015. "The Emergence of Network Media Logic in Political Communication: A Theoretical Approach." New Media \& Society 17(8): 1241-57. 
Kriesi, Hanspeter. 2013. Democracy in the Age of Globalization and Mediatization. Basingstoke: Palgrave Macmillan.

Kruikemeier, Sanne, Katjana Gattermann, and Rens Vliegenthart. 2018. "Understanding the Dynamics of Politicians' Visibility in Traditional and Social Media." The Information Society 34(4):215-28.

Kuhn, Raymond. 2005. "Where's the Spin? The Executive and News Management in France." Modern \& Contemporary France 13(3):307-22.

Kumar, M. J. and A. Jones. 2005. "Government and the Press: Issues and Trends." Pp. 226-47 in The Press, edited by G. Overholser and K. H. Jamieson. Oxford: Oxford University Press.

Landerer, Nino. 2013. "Rethinking the Logics: A Conceptual Framework for the Mediatization of Politics." Communication Theory 23(3):239-58.

Lengauer, Günther, Patrick Donges, and Fritz Plasser. 2014. "Media Power in Politics." Pp. 171-95 in Political Communication Cultures in Europe. Attitudes of Political Actors and Journalists in Nine Countries, edited by B. Pfetch. Basingstoke: Palgrave Macmillan.

Manheim, Jarol. 1998. "The News Shapers: Strategic Communication as a Third Force in News Making." Pp. 421-29 in The Politics of News and the News of Politics, edited by D. A. Graber, D. McQuail, and P. Norris. Washington, DC: Congressional Quarterly Press.

Marcinkowski, F. and A. Steiner. 2014. "Mediatization and Political Autonomy: A Systems Approach." Pp. 74-89 in Mediatization of Politics. Understanding the Transformation of Western Democracies, edited by F. Esser and J. Strömbäck. Basingstoke: Palgrave Macmillan.

Matthes, Jörg, Peter Maurer, and Florian Arendt. 2019. “Consequences of Politicians' Perceptions of the News Media.” Journalism Studies 20(3): 345-363.

Maurer, Peter. 2011. "Explaining Perceived Media Influence in Politics." Publizistik 56(1): 27-50.

Meyer, Thomas M., Martin Haselmayer, and Markus Wagner. 2020. "Who Gets into the Papers? Party Campaign Messages and the Media." British Journal of Political Science: 50(1): 281-302.

Negrine, Ralph and Darren G. Lilleker. 2002. "The Professionalization of Political Communication: Continuities and Change in Media Practices." European Journal of Communication 17(3):305-23.

Nimmo, Dan and Georgie Anne Geyer. 2014. Newsgathering in Washington: A Study in Political Communication. 1st edition. New Brunswick; London: Aldine Transaction.

Parmelee, John H. 2014. "The Agenda-Building Function of Political Tweets." New Media \& Society 16(3):434-50.

Paulussen, Steve and Raymond A. Harder. 2014. "Social Media References in Newspapers." Journalism Practice 8(5):542-51.

Pfetch, Barbara. 1998. “Government News Management." Pp. 71-97 in The Politics of News and the News of Politics, edited by D. A. Graber, D. McQuail, and P. Norris. Washington, DC: Congressional Quarterly Press.

Rosenbaum, M. 2016. From Soapbox to Soundbite: Party Political Campaigning in Britain since 1945. London: Springer.

Schulz, Winfried. 2004. "Reconstructing Mediatization as an Analytical Concept." European Journal of Communication 19(1):87-101.

Sellers, Patrick J. 2010. Cycles of Spin. Strategic Communication in the US Congress. Cambridge: Cambridge University Press. 
Sheafer, Tamir. 2001. "Charismatic Skill and Media Legitimacy An Actor-Centered Approach to Understanding the Political Communication Competition." Communication Research 28(6):711-36.

Sheafer, Tamir and Shaul Tzionit. 2006. "Media-Political Skills, Candidate Selection Methods and Electoral Success." The Journal of Legislative Studies 12(2):179-97.

Strömbäck, Jesper. 2008. "Four Phases of Mediatization: An Analysis of the Mediatization of Politics." The International Journal of Press/Politics 13(3):228-46.

Strömbäck, Jesper. 2011. "Mediatization and Perceptions of the Media's Political Influence.” Journalism Studies 12(4):423-39.

Strömbäck, Jesper and Frank Esser. 2014. "Mediatization of Politics: Towards a Theoretical Framework." Pp. 3-28 in Mediatization of Politics. Understanding the Transformation of Western Democracies, edited by F. Esser and J. Strömbäck. Basingstoke: Palgrave Macmillan.

Strömbäck, Jesper and Peter Van Aelst. 2013. "Why Political Parties Adapt to the Media Exploring the Fourth Dimension of Mediatization." International Communication Gazette 75(4):341-58.

Tresch, Anke. 2009. "Politicians in the Media: Determinants of Legislators' Presence and Prominence in Swiss Newspapers." The International Journal of Press/Politics 14(1): 67-90.

Tsfati, Y. 2017. "Public and elite perceptions of news media in politics". In K. Kenski \& K. Hall Jamieson (Eds.), The Oxford handbook of political communication (pp. 565-580). NY: Oxford University Press.

Van Aelst, Peter, Bart Maddens, Jo Noppe, and Stefaan Fiers. 2008. "Politicians in the News: Media or Party Logic? Media Attention and Electoral Success in the Belgian Election Campaign of 2003." European Journal of Communication 23(2):193-210.

Van Aelst, Peter, Adam Sehata, and Arjen Van Dalen. 2010. "Members of Parliament: Equal Competitors for Media Attention? An Analysis of Personal Contacts Between MPs and Political Journalists in Five European Countries." Political Communication 27(3): 310-25.

Van Aelst, Peter, Gunnar Thesen, Stefaan Walgrave, and Rens Vliegenthart. 2014. "Mediatization and Political Agenda Setting: Changing Issue Priorities?” Pp. 200-222 in Mediatization of Politics: Understanding the Transformation of Western Democracies, edited by F. Esser and J. Strömbäck. Basingstoke: Palgrave Macmillan.

Van Aelst, Peter and Stefaan Walgrave. 2011. "Minimal or Massive? The Political AgendaSetting Power of the Mass Media According to Different Methods." The International Journal of Press/Politics 16(3):295-313.

Van Aelst, Peter and Stefaan Walgrave. 2016. "Information and Arena: The Dual Function of the News Media for Political Elites: Information and Arena." Journal of Communication 66(3):496-518.

Vos, Debby. 2013. “The Vertical Glass Ceiling: Explaining Female Politicians' Underrepresentation in Television News." Communications - The European Journal of Communication Research 38(4):389-410.

Vos, D. 2014. "Which politicians pass the news gates and why? Explaining inconsistencies in research on news coverage of individual politicians". International Journal of Communication, 8, 2438-2461.

Wells, Chris, Dhavan V. Shah, Jon C. Pevehouse, Jung Hwan Yang, Ayellet Pelled, Frederick Boehm, Josephine Lukito, Shreenita Ghosh, and Jessica L. Schmidt. 2016. "How Trump Drove Coverage to the Nomination: Hybrid Media Campaigning." Political Communication 33(4):669-76. 
Wolfsfeld, Gadi and Tamir Sheafer. 2006. "Competing Actors and the Construction of Political News: The Contest Over Waves in Israel." Political Communication 23(3): 333-54.

Appendix A. Frequency distributions (\%) of perceptions of media importance across back-bench $(\mathrm{N}=94)$ and front-bench MPs $(\mathrm{N}=48)$
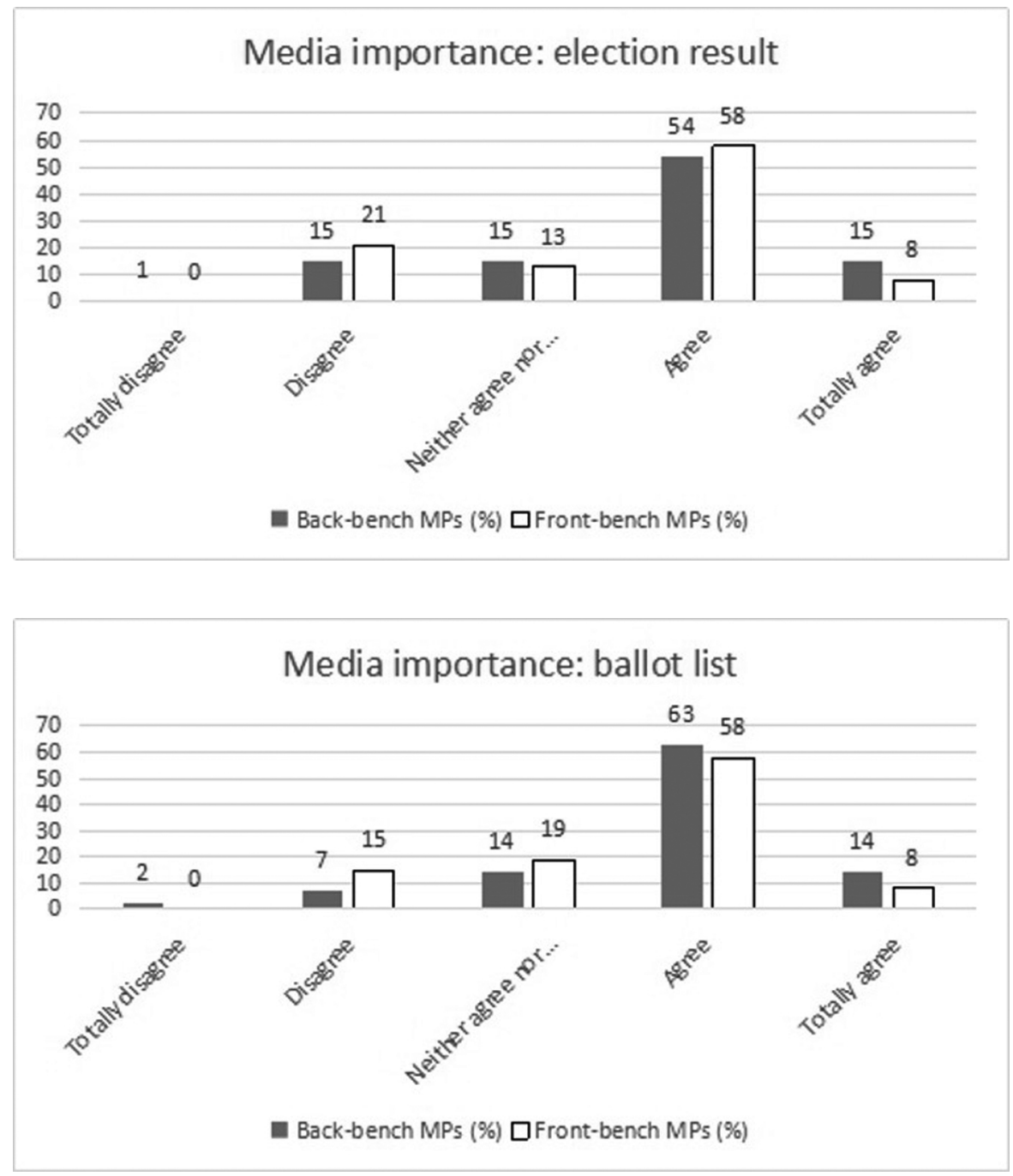


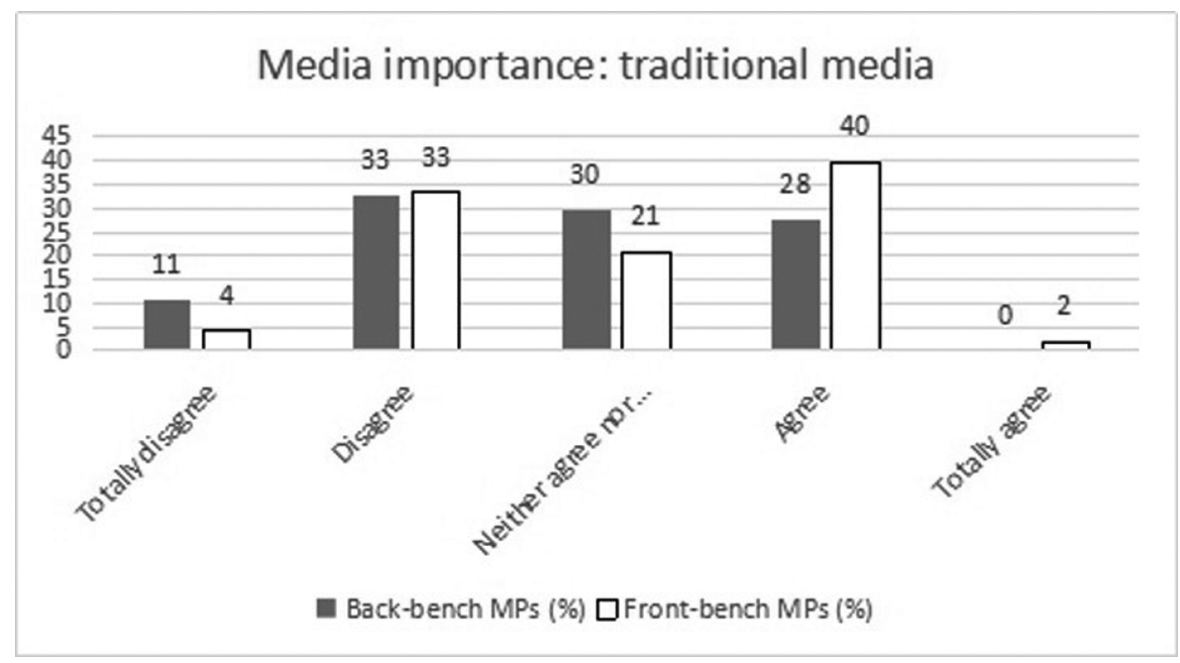

Appendix B. Distributions of press releases, press events and tweets across backbench $(\mathrm{N}=94)$ and frontbench MPs $(\mathrm{N}=48)$

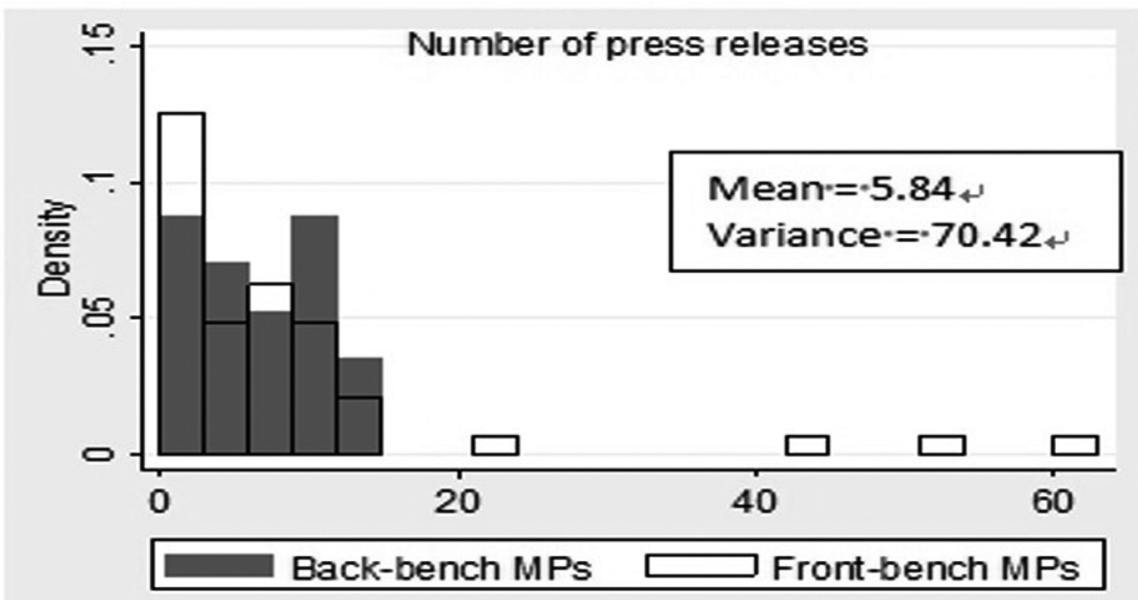



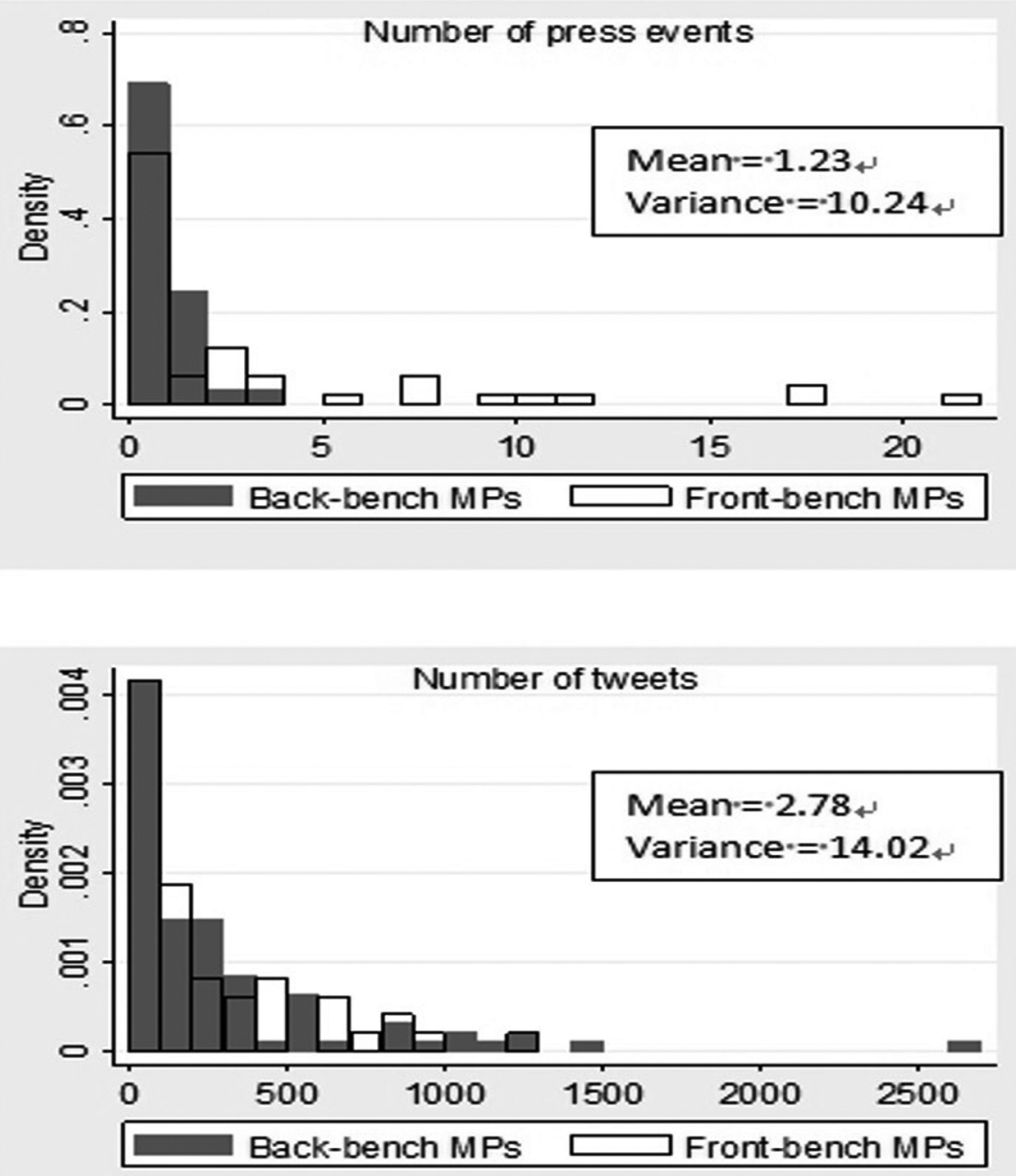
Appendix C. Distributions for media training, employees' media work time and contact with journalists across backbench $(\mathrm{N}=94)$ and frontbench MPs $(\mathrm{N}=48)$
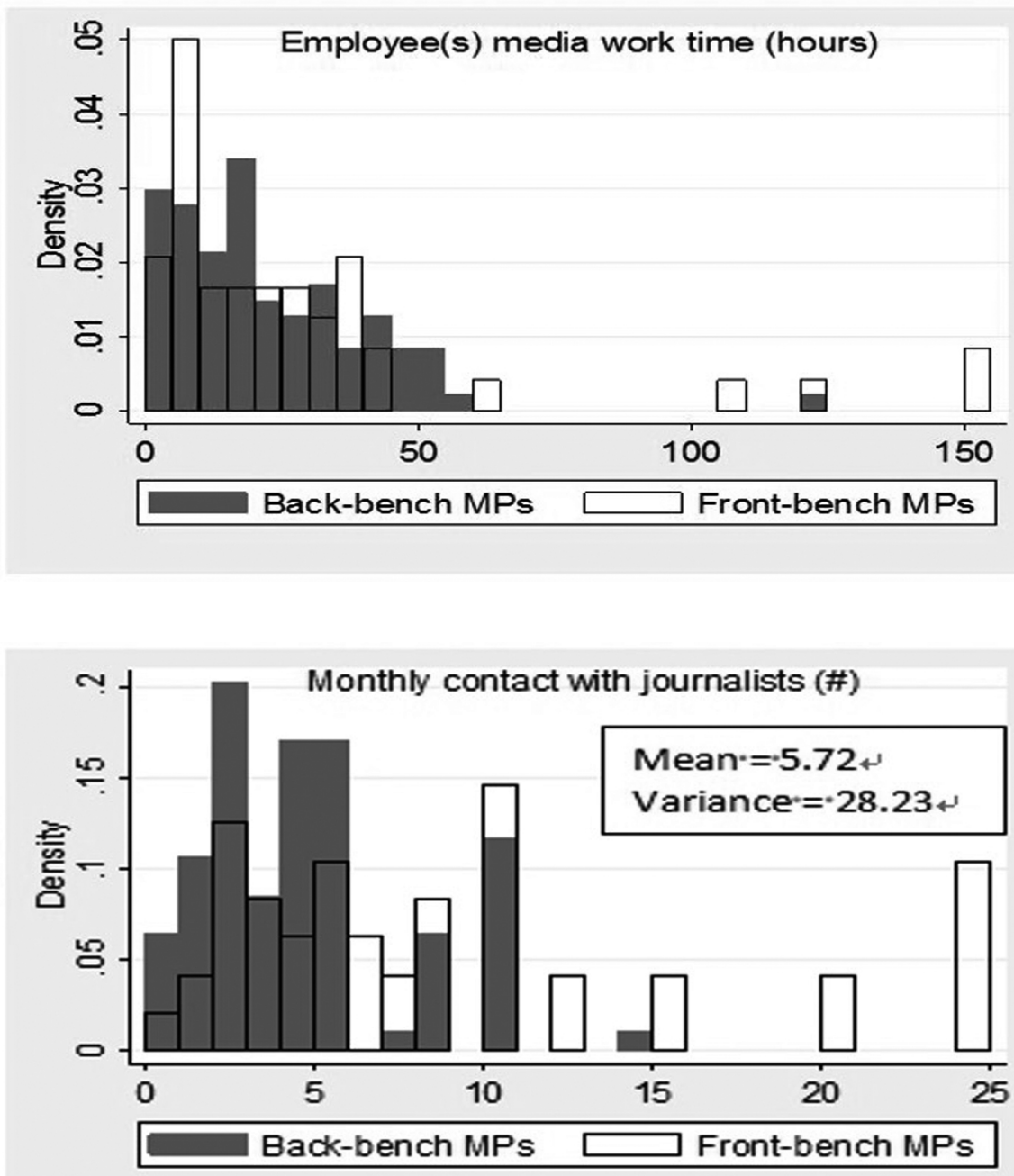


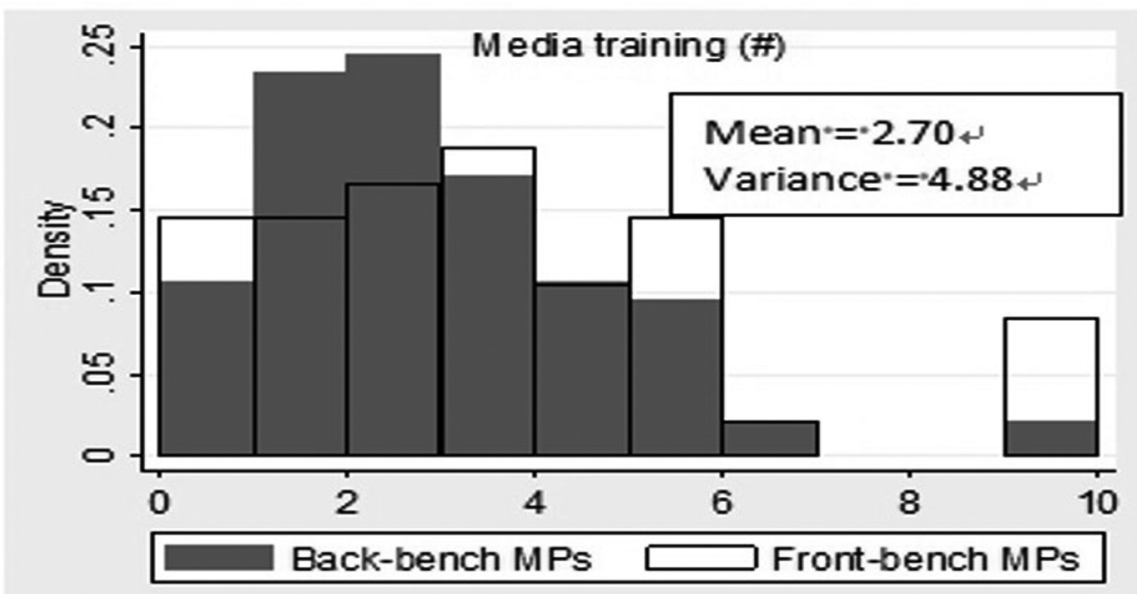

Appendix D. Distributions of appearances in television news, print newspapers and news websites $(\mathrm{N}=142)$

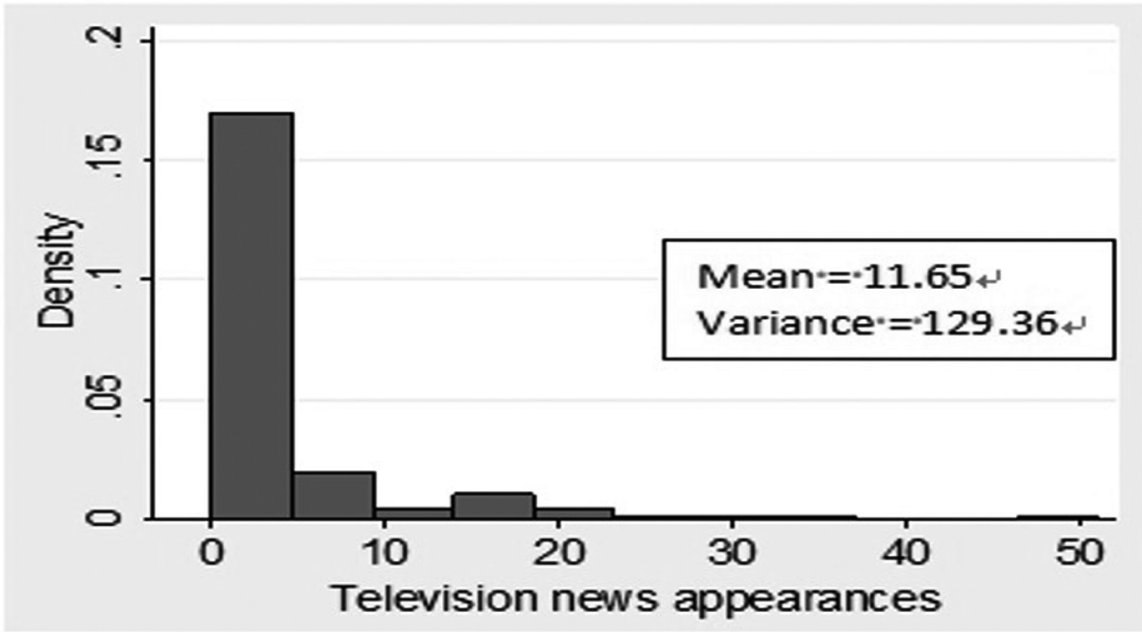



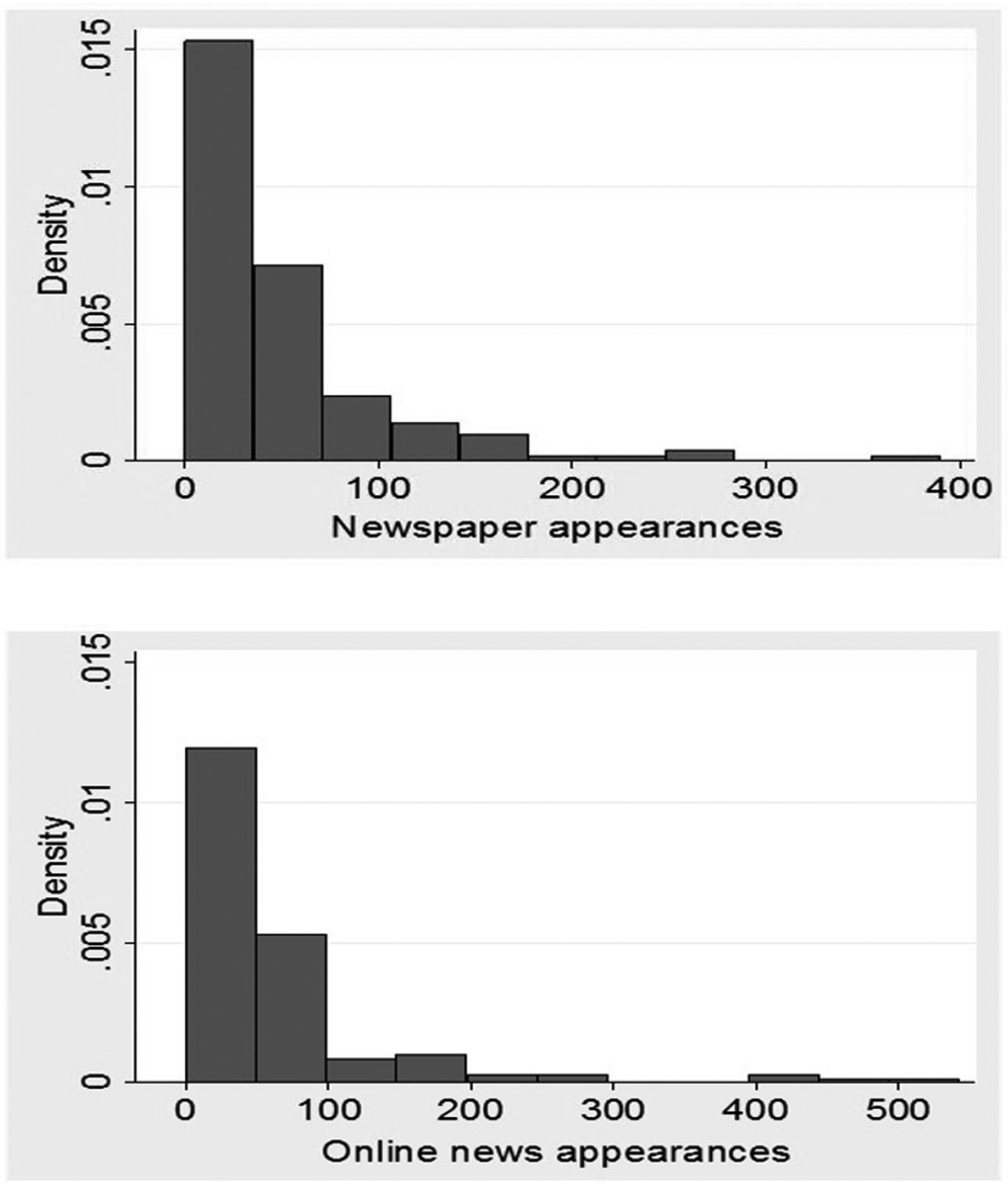